\title{
Conformity visa-vi transformational conversion in mission: Towards a self-transcendental mission agenda

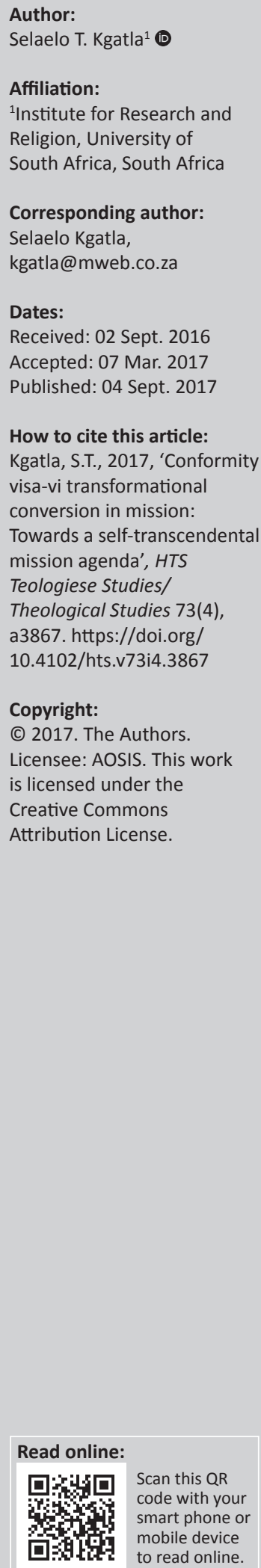

In this article, the author discusses the concept of conversion as opposed to conformity to a religious tradition without internal self-assertiveness. A transcendental mission understanding as opposed to an immanent agenda for liberation is proposed as an alternative solution. He analyses the role played and the contributions made by missionary enterprise and the liberation theologies in South Africa as they shaped the path for liberation. The white churches and state theologies sought to produce black conformists to the system; liberation theologies resisted the conformity mentality and fought for an egalitarian and free society. Both movements failed to embrace a transcendental methodology that would go beyond the secular boundaries and bring about transformational and empowering spirituality. This article suggests new spirituality for life and affirmation that would work against self-hate among the previously oppressed and self-guilt among the previously oppressing ruling class. It seeks ways to heal broken relationships through authentic empowerment and transformation.

\section{Introduction}

This article is drawn from the research project entitled 'Conformity, Change and Conversion: Towards the Missiology of Self-Transcendence among the Northern Sotho People in South Africa' conducted on the advent of the new political dispensation of South Africa in the early 1990s. The research was prompted by the contradictions in state and church theologies that were trying to lull black people in South Africa to tolerate the apartheid agenda. Against this pacification of the status quo black people waged a relentless liberal struggle for survival against the death orchestrated by the regime. The contestations were invariably rested on the Christian meaning of justice, equality and freedom of life as elucidated in John 10:10, particularly for the black people in the country.

Key concepts that undergirded the study were conformity, change and conversion in the Christian mission as these concepts were crucial for the understanding of the holistic mission of God to the world. In that study, a proposal was made for a missiology of self-transcendence that would make an authentic religious breakthrough and contribution to the agenda for mission in a racially divided and brutally dominated country. The concept of self-transcendence was borrowed from Lonergan's understanding of religious conversion and was employed to pave a new orientation towards understanding and directing a realistic conversion in a country which was dominated for centuries by the false consciousness of Christian conversion.

It is the contention of the author that in the three centuries of its existence in South Africa, the church's understanding of mission was to a large extent marred by racial prejudices, greed, economic interest, designed inequality, political interest and dominance for the promotion of white people's survival (Magwira \& Kgatla 2015a:473). Black Africans were viewed as a threat to white supremacy and interest (Elphick 2012:219).

By self-transcendence, Lonergan meant going beyond the self (in Doran 2011:12), breaking, as it was, human-made boundaries and reaching beyond old horizons. Within Lonergan's understanding, humans have a dynamism which keeps searching beyond for something authentic and real (Ibid:12) which he calls the 'love of God'. Human beings are ever searching for God consciously and unconsciously until they fall in love with God. When they 'fall in love with God', the Holy Spirit floods their hearts so that they experience a new relationship with the transcendent reality. In this article, the researcher revisits these concepts and tries to illustrate their relevance for mission in our time. 


\section{Lonergan's authenticity, self- transcendence and conversion}

In his guiding orientation on self-transcendence, Lonergan (in Doran 2011:1) elucidates his understanding of religious conversion by introducing three concepts: authenticity, selftranscendence and conversion. According to Lonergan (in Doran 2011:2), the three terms are interrelated as 'authenticity is achieved in self-transcendence, and consistent selftranscendence is reached only by conversion'. As the process of religious conversion makes human beings consistently self-transcending, self-transcendence requires that one undergoes an ongoing process of conversion. This process of conversion entails the notion of horizon (2011:3). By horizon, Lonergan refers to the limit of one's field of vision which changes as one develops intellectually (2011:3). According to this metaphorical representation, conversion entails a radical shift in one's horizon that repudiates characteristic features of the old (Ibid:3). However, Lonergan warns that not every shift in one's life is conversion. He refers to these sequences of events that do not constitute conversion as 'breakdown'. They may be radical occurrences in one's life but they may not necessarily constitute authentic conversion (Lonergan 1972:290). Moreover, religious conversion is not guaranteed by belonging to a religious community.

\section{Conversion from and conversion to}

In deepening his understanding of religious conversion, Lonergan proposes that if self-transcendence is the goal, the end point, there must be a starting point (1972:20). The process of religious conversion frees a person from self-enclosure and radical lovelessness. Therefore, religious conversion is the twofold process of being loved unconditionally and responding to that radical love by cooperating in the process unconditionally (1972:2990). Lonergan argues that 'religious conversion is a movement from self-absorption, radical lovelessness or self-enclosure into self-transcendence' (Ibid). True conversion has elements of self-detachment and selfunrestrictedness. Authentic religious conversion is opposed to conformity in all its forms. Therefore, the next question should ask: what is conformity?

\section{Conformity, change and conversion}

In this article, the author argues that a change of religion or affiliation from any traditional religion to Christianity in the non-developed countries (as it was the case elsewhere) was wrought with many controversies and contradictions. The change from one religion to another was not always a genuine conversion but sometimes a result of outside and inside pressures that could be characterised as conformity. This was the case with many black South Africans. They underwent, to a large extent, conformity to a dominant culture because of external pressure which either induced submission or enforced crushing defeat to ensure their submission. Incentives such as the setting up of health clinics, schools, colonial regimes and social services centres represented a form of hegemony and power over the indigenous people and encouraged a form of compliance from them (Khapoya 2012:101). Military might and their resultant defeat of local chiefs and the right to rule over the defeated had the indomitable effect of enforcing physical and psychological surrender. Consequently, their conformity came about when they entered into a social situation where they were confronted with a dilemma of choice. The social framework in which they found themselves compelled them to adjust, conform or realign their behaviour and religion (Berg \& Bass 1961:3) in line with the invading culture. Uncertainty as to how they should respond to overbearing conditions led them to conformity. Authentic conversion that included fundamental shifts in attitudes, opinions, understandings and convictions brought about by a genuine spiritual experience that dislocates the individual from his or her previous orientations in order to connect with God was rarely realised (Ibid:4).

Social scientists such as psychologists, anthropologists and sociologists have written extensively on the subject of conformity and change (Bascon \& Herskovits 1975; Berg \& Bass 1961; Cohen 1963; Cohen \& Lee 1975; Hall 1982; Kiesler \& Kiesler 1970; Slaby \& Tancredi 1983), and more recently, Whalen and Laland (2015) and Tayler and Bloomfield (2009) have written about the subject as well. Tayler and Bloomfield (2009:753), for example, define conformity as the change of actions or attitudes caused by pressure from some real notional groups. They divide conformity into rational conformity and irrational conformity (2009136). According to them, conformity is guided by thinking, judgement or reasoning that seeks existential safety. Irrational conformity, in contrast, is the behaviour subjects present when they are guided by intuitionistic and instinctive activities influenced by outside agencies (Ibid:136). It is the contention in this article that in many instances where the original religious world view was altered to embrace the external one, and where some form of pressure was exerted to bring on compliance, conformity was anchored. Often, this kind of change was mistakenly called conversion.

More often than not, this pressure came in the form of punishment or incentive or even reward and desire for protection. In this respect, Kiesler and Kiesler (1970:2) argue that conformity is compliance to outside pressure and private acceptance, which suggests an alteration of previous behavioural direction. If force is used, the change is forced on the subjects for a desired direction. In this case, the person does not act as he or she wishes but changes his or her opinions and beliefs in terms of the dominant group's desires. Berg and Bass (1961:1) argue that in order for conformity to take place, a framework brought about by external and internal anchorages is crucial. Hall (1982:6) contests that power and control as exercised with a large measure of forced consent is actualised within a social setting. Similarly, Hays and Goldstein (2015:17-26) argue that illegitimate power increases conformity because this kind of power is often brutal. In some missionary endeavours, manipulation made many 'convents' who were not true at heart. According to 
Hall (1982:7), there is a willing consent and forced consent to political or religious ideologies. Sometimes both forced and willing consents result in conformity (in order to avoid pain or loss of favour) with built-in resistance that could erupt as a descent at a later stage (Magwira \& Kgatla 2015a:365-383). Black relentless resistance in search for freedom in the face of state brutality in South Africa epitomises this movement.

In line with this assertion, Davenport (1989:230) mentions that the black protest movement against unjust apartheid policies, which was not limited to political activism, was led by the leaders of the South African Native National Congress (SANNC) and others. This resistant protest led to the formation of many African independent churches which were founded to expose the conformity imposed on them by earlier missionaries, epitomising the widespread agony the African people had with the mission policies of their time. Furthermore, Davenport (1989:231) mentions religious leaders such as Mangena Mokone, Nehemiah Tile and James Dwane who moved out of the white churches to form their own separate churches. There were, however, many reasons which gave rise to the schism from the white churches, but shaky motives on which their conversion was built were some of the major causes for the split. Some scholars call this open irruption and resistance nonconformity which was demonstrated openly when the subjects came of age (Kiesler \& Kiesler 1970; Slaby \& Tancredi 1983; Tayler \& Bloomfield 2010; Woodersv 2014). In addition to this, Wooders (2014:743) argues that social norms and the coordination of behaviour within social groups, which were kept in artificial equilibrium, disintegrated when the pressure of resistance was made to bear on it. All dominant religious groups strove for social stability that favoured their interests wherever they did their missionary work for once that was achieved there was a sigh of relief for the dominant group and a form of conformity was achieved. Missionary movements in South Africa were not exonerated from this manipulative process as they sought to proselytise and convert Africans to their form of Christianity (Goodman 1994:1; Khapoya 2012:101).

\section{Variables influencing conformity}

Berg and Bass (1961) cite the following as variables influencing conformity: age, status, wealth, gender, group and religious background. Many agencies use formal control systems to influence motivation for change by employing the variables above. Religious crusaders including 'Christianising, civilising and proselyting agencies used monitoring, enforcing and incentives to induce desired behaviour in their subjects' (Tayler \& Bloomfield 2009753). People who were dislocated from the society were labelled outcasts either because of their disdainful behaviour or nonconformity to their societal religious practices and fell prey to missionary advances. These groups were easy to poach and resettle outside of their communities to form mission stations (Magwira \& Kgatla 2015a:783). Those whom missionaries and colonial rulers could not hold had formal controls such as laws and rewards based on norms applied to them in order to influence them for their purpose. These rewards included European clothes, education and religion (Bascon \& Herskovits 1975:6). The social controls tended to be more brutal, especially in totalitarian regimes (Slaby \& Tancredi 1983:16). This incorrect motivation for change was incorrectly termed conversion, whereas it was a mere conformity (Tayler \& Bloomfield 2009:754). Norms found in religions can exert powerful influence that results in conformity. Slaby and Tancredi (1983:10) cite rules, regulations and codes of conduct as forms of formal and informal rules in a society. Individuals and groups that cannot be kept in alignment with societal goals by moral rules were often controlled by strict legal systems by those in authority as already indicated above. Where control was used to force behavioural conformity, no authentic conversion took place for there was no internal selfassertiveness that enhanced conversion (Ibid:10).

South African political history is replete with examples of cruelty to nonconforming behaviour, especially when applied to black people. If black people showed self-assertiveness that was not in line with apartheid regime desires, they were subjected to constant harsh treatment in order to force conformity. Slaby and Tancredi (1983:13) maintain that in such circumstances where there is no self-assertiveness and self-expression, religious conversion cannot easily take place. Controls work against self-assertiveness and it is detrimental to individual religious freedom and creativity (Ibid:13). The harmonisation of society needs and individual needs is crucial if self-actualisation is to be achieved, and religious conversion is not authentic when there is an obstruction of individual freedom and expression (Ibid:13).

In colonial South Africa, black people were controlled through heinous laws passed in parliament and missionaries were invariably affected or even influenced by some of the laws in their work (Kgatla 1992:471). In their religious agenda, black people had no control or any assertiveness that espoused their liberation. White culture was Christian and black culture was 'heathen' (Ibid:471). Where force was not used, a new form of African identity was crafted as Khapoya (2012:101) has observed. African languages were banned at missionary institutions and their customs and heritage were discouraged; Africans were provided with new clothing and given names at churches and schools. Sometimes they were subjected to some psychological tortures like being refused admission to missionary schools and even being ridiculed for what they were (Khapoya 2012:102).

In this article, therefore, an argument is advanced that much of what was said to be Christianity in South Africa was enforced, monitored and controlled by both legal and religious systems and lacked self-assertiveness and, thus, was not authentic Christian conversion. The proliferation of many cults and religious groupings in South Africa was accelerated partly because they did not have strong roots from the life and teachings of mainline churches as the latter lacked pure motives for mission. Their initial change to Western Christianity was, in some respects, the result of 
pressure to conform but not a strong personal conviction to be the true Christians they were expected to be. People who changed from African traditional religious systems to Western beliefs or behaviours did not always do so as a result of true Christian conversion but as a result of psychological pressure to conform. As time went by and many African states acquired their political and social independence, the centre could no longer hold because the constituent elements that tied them together were not based on strong bonds of religious conversion. Signs of coercion started showing in which authentic conversion was lacking. In this respect, Khapoya (2012:1020) observes, as already indicated, that Western religion instilled submissiveness in its subjects by insisting that life on earth was temporary and only used to prepare them for better life later. To qualify for the glorious life to come, one had to exercise virtues of blind forgiveness, submissiveness, longsuffering and patience even to those who were sinning against them (2012:102).

\section{South African theologies of self-interest and self-preservation}

Much has been written about white theologies in South Africa that used to promote the protection of white interest and survival (Kairos Document 1985). Equally, much has been written about black theologies of liberation and life (Ackah 2015; Boesak 2015; Vellem 2015). Under the two main white theologies of self-interest, black theologians unmasked a monumental culmination of racism and racial agenda which was propelled under the cloak of Christianity. The white self-interest was somehow wittingly and unwittingly embedded in mission policies of dominant white churches (Magwira \& Kgatla 2015b:447). These two theologies of selfinterest were state theology and church theology (Kairos Document 1985).

White Afrikaner churches had the same agenda as that of the state when it came to the relegation of black people to the status of non-persons (Vellem 2015:8) and, therefore, shared the aspirations of the state theology that misused and abused some biblical texts for their political purposes (Kairos Document 1985:2). Under the state's totalitarian quest to exclude black people from the wealth of the country, the representatives of this theology used the Bible to justify their brutal policy towards black people (Ibid:5) and ordered the black population to be subjected to apartheid policy. Salvation was thus made to be in line with human selfish socio-political and economic agendas. Economic, social and cultural interests were safeguarded at the expense of black people (Magwira \& Kgatla 2015a:365-383). The suppression of human rights under the claim of law and order and the fear or threat of communism (Kairos Document 1985:4) were maintained ruthlessly.

The second branch of white theology of the time was church theology (Kairos Document 1985:5). This theology was mainly followed by English-speaking churches that espoused an unrealistic optimism towards the resolution of the South African political crisis. They held unrealistic views that reconciliation was possible in a situation where the dominant party had brutally abused the human rights of the powerless (Magwira \& Kgatla 2015b:447). This brand of theology believed that reconciliation between the state and the struggling masses was possible without justice, restoration and reinstitution (Kairos Document 1985:6). The fact of the matter was that they were also indirectly benefiting from the status quo. However, reconciliation without facing the reality of apartheid and the forgiveness that should precede it was not realistic. The relationship between white churches and the South African government was truly symbiotic and it could not be said that it had inspired liberating Christian conversion. At best, it suppressed people to make them conform to its demands rather than to God's transcendent empowering encounter. God's purpose was effectively replaced by a human agenda.

The contention in this article is that Christian conversion is never the result of human actions. Human endeavours lead to conformity to a dominant group's religion. For the authentic Christian conversion to be realised, human initiatives should be soaked in Trinitarian initiatives where transcendent and transformed relationships in mission are made possible. The concept Missio Dei is relevant here for the empowerment of converts. The Trinity must be their starting point for their new discovery with God (Newbigin in Tennent 2010:67). The Trinity, in the face of conversion, remains the only authentic basis on which the church proclaims the Gospel to the world (Newbigin in Tennent 2010:67).

According to Newbigin (in Tennent 2010:68), the Missio Dei paradigm shift presupposes a new understanding of mission from Christendom to the present day. The Oxford Dictionary defines transformation as a complete change in how things have been done to date to a new empowering order. If a change has been effected through Missio Dei, one can say that conversion has undergone a complete 'transformation'. Transformation is a missional agenda that seeks to change people's perceptions, lifestyles and stereotypes of who God is (Kgatla \& Mkhwanazi 2015:19). Missio Dei presupposes a fundamental change that ushers in the Kingdom of God among the people in a radical way. Transformation brings new change and life where there was no life previously for the good of the whole world.

\section{Towards authentic conversion: Transcendence and conversion for the kingdom}

Transcendence signals what is beyond - beyond what cannot be subjected to human manipulation and control. Schwartz (2004:viii) defines transcendence as the ground of humility, as something humans cannot boast about. It is an epistemological break that cannot be reduced to human whims. It is the experience that exceeds human conceptualisation and stretches out beyond absoluteness and immanence. According to Schwartz (2004:viii), 
transcendence defies prediction, eludes idolatry, creates a crack in immanence and is resistant to a common course. Transcendent experience is opposed to imposing immanent humanism that promises salvation in human endeavours (Doran 2011:2). Transcendent experience is a delirious rupture that reaches beyond human limitations or scopes. As much as it is a desirable thing for humans to pursue life, liberty and its fullness, happiness, freedom and justice are never sufficient to limit one's search to the realm of immanence (Schwartz 2004:x). Transcendence means going back to the source of all goodness and recreating a world where God is not only present but also rules (Ibid:x). Solutions to societal problems achieved on the basis of nonbelief, no matter how intellectual they may appear, are not authentic as long as they are found outside of the Trinitarian mandate. Closely related to transcendence is self-transcendence that underscores the understanding that humans are incomplete and by nature are thrusting themselves into an incomplete future (Doran 2011:1). Self-transcendence presupposes that there can never be knowledge of God separate from the dynamic relationship with him (Taylor 2004:1).

In tyrant and totalitarian regimes where human rights are not only ignored but denied, justice sought for political and economic emancipation by the underside of history, social and cultural liberation as well as the authentic deliverance should come under the horizon of transcendence - a justice that is beyond formal categories of human programmes (Schwartz 2004:xi). In transcendent conversion, human beings are called to be beyond themselves and seek the reality that is from beyond. Mission that underscores the transcendent experience realises completeness in the struggles for liberation with God. God is and can only be known in relationship with him. Outside of the dynamic and complete relationship with him, there can be no liberating and saving knowledge of him. Therefore, transcendent conversion, according to Schwartz (2004:xi), is a delirious rupture of immanent experience, a realm of the impossible in human views that breaks into the possibility and creates new spaces where humans can interact with God as he saves their lives (Ibid:xi).

\section{The black liberation struggle and the notion of self-transcendence}

The black struggle against the demons of apartheid in South Africa was heralded by the whole free world as authentic and essential. Ecumenical bodies such as the World Council of Churches, Lutheran World Federation, Reformed Alliance of Reformed Churches and many others denounced apartheid as a crime against humanity (Fahlbush 1998). Indeed, humans could not be imagined to live under the tyranny of the apartheid regime and religious and civil sectors had a genuine and justifiable struggle to overthrow the regime. No amount of words could condemn the system enough. Many black theologians produced monographs depicting the liberation struggle in South Africa as orchestrated and led by God. The black theology of liberation was not only in discussion with black people in their struggle but was also their inspiration (Mofokeng 1983:20).

The adage that God has preferential option for the poor and the oppressed was widely canvassed. After the first democratic general elections in 1994, South Africa was given titles such as Madiba Magic, Rainbow Nation and many others. The world was promised a model of how reconciliation could be achieved among groups that were previously hostile towards one another. But today, the promise of the Madiba Miracle and Rainbow Nation has weathered into a false promise. Triple evils of the country, such as unemployment, inequality and poverty, have ranked the country as one of the most conflict-ridden countries in the world (Terreblanche 2012:24). Social commentators such as Tabane (2015) and Malala (2015) contend that the country is on the brink of total collapse. The pertinent and pressing question is what went wrong after the supposedly glorious start of 1994? One could just conclude that the foundation for self-transcendent conversion was never correct. The assumptions made in 1994 in respect of the ability of South Africans to dust away the ashes of apartheid were never correct. Although the struggle brought liberation to the country in Africa, the methodology that undergirded it was never coached in self-transcendent connectivity.

In a similar research project on the same topic in the early 1990s, the researcher argued that the black struggle for liberation lacked the element of self-transcendence; the struggle was lacking in terms of allowing an authentic connection with God. Although it was comprehensive humanly speaking, it was waged on human levels. God was eclipsed by the 'smoke oozing from [the] township' and the dust from rural places as the struggle waged on. Human anger was unleashed uncontrollably, and institutions such as the Truth and Reconciliation Commission mesmerised and stifled the creativity of people in reaching beyond their limitations.

The researcher should haste to state that in the liberation struggle, black people who were pursuing the ideals of the struggle for liberation in South Africa were in search of life, liberty, freedom and justice as promised by God. Their pursuit for these ideals was authentic and proper. Their search for liberty, freedom, dignity, human rights and franchise was constructed on the principle that would contribute happiness to all living in the country (African National Congress 1955). However, more often than not, the sources for altruistic sacrifices were found entirely within the realm of immanence.

In this respect, one should also contemplate Taylor's (2004:5) assertion that humans' preoccupation with their problems and the need to free themselves may eclipse God in their lives, as indicated earlier. God may easily disappear from their pursuit for freedom and justice. Disenchantment and an overbearing burden to shake off the yokes of oppression may contribute to the eviction of transcendence from the 
public sphere (Ibid:8). The distancing of God from humans is completed when the immanent human option is embraced at the expense of a self-transcendent epoch (Ibid:8). Reason, as the ability to reach the level of universality and in that way distances humanity from God in its pursuit to find freedom and justice (Taylor 2004:8), is part of the immanent option. Sympathy as an innate tendency that pushes people to help their fellow human beings may also cut any formal relationship with God. In this sense, humans feel that they can achieve ideals that would ensure tranquillity in their lives without involving God. All these, according to Taylor (2004:5), create a world where truths of faith are both far from being evident and are strongly contested.

In contrast, self-transcendence means going back to the source of life and recreating the world where God is present. Instead of living in the eclipse, one tries to go beyond it (Schwartz 2004:x). Social projects for the welfare of all followed an immanent option of getting new meaning in transcendence programmes such as eradicating hunger and illness; preventing genocide; fighting inequality, injustices and the effects of natural disasters; and, in fact, bringing hope to those who do not have hope. All of these issues may be attended to in the realm of immanence and get new empowering meaning when they are pursued under the realm of transcendence. The love of God has a more prominent place where transcendence appears in the world (Taylor 2004:9).

\section{Conclusion: Christian conversion reiterated}

Conversion, like conformity, involves some form of change. It is a dynamic process and it is never static. Ullman (1989:189) refers to religious conversion as a wide range of experiences that sometimes occurs abruptly and sometimes gradually. In both cases, it involves an increased commitment within the framework of the person's own circumstances (Ibid:5). Rambo (1993:2) too sees conversion as a process but not as an event. Conversion, according to Rambo (1993:3), is a deeper conviction of God's presence that is sometimes threatening, punitive and is contextually determined. Conversion is a shift from one belief to another in a fundamental way (Jindra 2014:8). According to Lonergan (in Doran 2011:5), conversion always occurs in incremental steps deepening in the realm of transcendence in which God is known and loved. In conformity, people change either because of some form of external and internal pressure that is accompanied by some form of sanction or reward for adhering to certain norms and other external pressures that enforce the desired change of those in charge of the system. Psychological pressures such as anxiety, fear, love of beauty and fashion may also bring about conformity (Berg \& Bass 1961:1-2). Such change is never authentic because, to a large extent, it is imposed and lacks personal commitment from the subject to a newly found experience that is initiated by hearing the Word (Romans 10:17) and being inspired by the Holy Spirit and directed by God the Father. In authentic conversion, in contrast, human endeavours are never considered an issue and God is glorified. Human imposed norms and rules are restrictive; they can only produce false change that is not liberating and does not free the soul for God. For Gooren (2010:10), the original meaning of conversion is found in the Greek word metamelomai used in the New Testament, which refers to the change of mind and heart. The implication here is that repentance and rebirth are both personal and communal in character (Wall 1995:2) and they are transformational.

Some forms of religious conversion are propelled by fear, a need for protection and desire for increased devotion or empty piousness (Finn 1997:19). Rambo adds anguish, turmoil, despair, conflict, guilt and other difficulties in life as some elements that influence conversion. It is further influenced by a matrix of relationships, expectations and experiences (Rambo 1993:3). Conversion refers to a change in how a person understands, values and lives in his or her life (Finn 1997:239). It should be added here that commitment to a devout religious life or a change from one religious affiliation to Christian religious tradition does not necessarily constitute a true conversion. True conversion is anchored in life-transforming experiences initiated in the encounter with the three persons in Trinity. Lonergan (in Davies 2013:97) goes a step further. According to him, religious conversion is 'being in love in an unrestricted fashion'. At the heart of religious conversion, according to Moloney (2004:123-134), lies a saving gift from above, from the heart that loves without restriction. In this religious experience (Davies 2013:97), human beings are empowered to overcome the cognitive distortion that has restricted their culture and conditioned their own personal formation. Out of this human conditionality, Lonergan proposes an insight that depends on some other's unrestricted act of understanding (Ibid:97). A biblical metaphor from Malachi 3:7 is apt here: 'From the days of your forefathers you have been wayward and have not kept my laws. If you will return to me, I will return to you' (quoted by Finn 1997:21). Conversion takes place where God and humans meet and transformative spirituality between God and humans is made possible. The impact of such an encounter is seen in humans when they transform themselves into subjects of love (in Davies 2013:12).

\section{Acknowledgements Competing interests}

The author declares that he has no financial or personal relationships which may have inappropriately influenced him in writing this article.

\section{References}

Ackah, W.R., 2015, Contesting post-racialism: Conflicted churches in the United States and South Africa, University of Mississipi, Oxford, MS.

African National Congress, 1955, Sahistory.org.za, viewed 09 May 2016, from www. sahistory.org.za/congress-people-and-freedom-charter

Bascon, W.R. \& Herskovits, M.J., 1975, Continuity and change in African cultures, Phoenix Books, Chacago, IL.

Berg, I.A. \& Bass, B.M., 1961, Conformity and deviation, Harper \& Brothers Publishers, New York.

Boesak, A., 2015, Kairos, crisis and global Apartheid, 1st edn., Palgrave Maxmillan, New York. 
Cohen, B.P., 1963, Conflict and conformity: A probability model and its application, The MIT Press, Cambridge, MA.

Cohen, B.P. \& Lee, H., 1975, Conflict, conformity and social status, Elsevier, Amsterdam. Davenport, T.R., 1989, South Africa: A modern history, Macmillan, London.

Davies, D.J., 2013, Emortions and religious dynamics, Durham University, Durham.

Doran, R.M., 2011,. What Bernard Lonergan mean by 'conversion', Herder \& Herder, New York.

Elphick, R., 2012, The equality of belivers: Protestant missionaries and the Racial Politics of South Africa, University of KwaZulu-Natal, Scotville, MI.

Fahlbush, E., 1998, The encyclopedia of Christianity, vol. 5, Brill Publishers, Leiden.

Finn, T.M., 1997, From death to rebirth: Ritual and conversion in antiquity, Paulist Press, Mahwah, NJ.

Goodman, M., 1994, Mission and conversion: Proselytizing in the religious history of the Roman Empire, Clarendon Press, Oxford.

Gooren, H., 2010, Religious conversion and disaffiliation: Tracing patterns of change in faith practices, Palgrave MacMillian, New York.

Hall, S., 1982, Managing conflict, producing consent, The Open University Press, Milton Keynes.

Hays, N.A. \& Goldstein, N.J., 2015, 'Power and legitimacy influence conformity', Journal of Experimental Social Psychology 60, 17-26. https://doi.org/10.1016/j. jesp.2015.04.010

Jindra, I.W., 2014, A new model of religious conversion: Beyond network theory and social construction, Brill, Leiden.

Kairos Document, 1985, Kairos document, Institute for Contextual Theology, Johannesburg.

Kgatla, S.T., 1992, 'Conformity, change and conversion amomng Northern Sotho people: Towards a missiology of self-transcendence', Unpublished D.Th thesis people: Towards a missiology of self-transcendence', Unp
submitted to the University of South Africa, Unisa, Pretoria.

Kgatla, S.T. \& Mkhwanazi, F.S. 2015, 'The place of women ministers in the mission of the Methodist Church of Southern Africa', SHE 41(2), 180-197.

Khapoya, V.B., 2012, African experience, Oakland University, Oakland.

Kiesler, C.A. \& Kiesler, S.B., 1970, Conformity, Addison-Wesley Publishing Company, London.

Lonergan, B.J., 1972, Methods in theology, University of Toronto, Toronto.

Magwira, M.A. \& Kgatla, T., 2015a, 'Defining moments of the Dutch reformed mission policy between 1935 and 1947', South African Journal of Mission Studies 3(3), 365-383.
Magwira, M.A. \& Kgatla, T., 2015b, 'Mission driven by fear and dispair: The case of Kranspoort - The first Dutch Reformed Church mission station outside the Cape Colony', Stellenbosch Theological Journal i(2015), 471-490.

Malala, J., 2015, We have now begun our descent: How to stop South Africa losing its way, Jonathan Ball Publishers, Johannesburg.

Mofokeng, T.A., 1983, The crucified among the cross-bearers: Towards black christology, KOK, Kampen.

Moloney, R., 2004, 'Conversion and Spirituality Bernard Lonergan (1904-1984)', The Way 43(4), 123-134.

Rambo, L.R., 1993, Understanding religious conversion, Edwards Brothers, Inc., Grand Rapids, MI.

Schwartz, R., 2004, Transcendence: Philosophy, literature, and theology approach the beyond, Routledge, London.

Slaby, A. \& Tancredi, L.R., 1983, Collusion for conformity, Jason Aronson, New York.

Tabane, O.J., 2015, Let's talk Frankly: Letters to influential South Africans about the State of our Nation, Macmillan South Africa, Johannesburg.

Taylor, C., 2004, 'A place for transcendence?', in R. Schwartz (ed.), Transcendence: Philosophy, literature, and theology approach the beyond, pp. 1-10, Routledge, New York.

Tayler, W.B. \& Bloomfield, R.J., 2009, 'Norms, conformity, and controls', Journal of Accounting Research 49(3 June 2011), 753-790. https://doi.org/10.2139/ssrn. Accounting
1010167

Tennent, T.C., 2010, Invitation to world mission: A trinitarian missiology for the twenty-first century, Kregel, Grand Rapids, MI.

Terreblanche, S., 2012, Lost in transformation: South Africa's search for a new Future since 1986, KMM Review Publishing Company (PTY) Ltd, Santon.

Ullman, C., 1989, The transformed self: The psychology of religious conversion, Plenum Publishing Corporation, New York.

Vellem, V.S., 2015, 'Black theology of liberation: A theology of life in the context of Empire', Verbum et Ecclesia 36(3), 6. https://doi.org/10.4102/ve.v36i3.1470

Wall, G., 1995, Religious experience and religious belief, University Press of America, Boston, MA.

Whalen, A. \& Laland, K., 2015, 'Conformity biased transmission in social networks', Journal of Theoretical Biology 380, 542-549. https://doi.org/10.1016/j.jtbi.2015. 06.028

Wooders, M., 2014, 'Correlated equilibrium, conformity, and stereotyping in social groups', Journal of Public Economic Theory 16(5), 743-766. https://doi.org/10. $1111 /$ jpet.12078 